\title{
Sustainable use of California biomass resources can help meet state and national bioenergy targets
}

\author{
by Bryan M. Jenkins, Robert B. Williams, \\ Nathan Parker, Peter Tittmann, Quinn Hart, \\ Martha C. Gildart, Steve Kaffka, \\ Bruce R. Hartsough and Peter Dempster
}

Biomass constitutes a major renewable energy resource for California, with more than 30 million tons per year of in-state production estimated to be available on a sustainable basis for electricity generation, biofuels production and other industrial processing. Annually, biofuel production from these resources could exceed 2 billion gallons of gasoline equivalent, while providing opportunities for agricultural and rural economic development. Continuing research and large-scale demonstrations now under way will test alternative technologies and provide much-needed information regarding costs and environmental performance. Biomass can help meet state goals for increasing the amounts of electricity and fuels from renewable resources under the Renewable Portfolio Standard (RPS) and the Low Carbon Fuel Standard (LCFS), and can similarly help meet national biofuel targets under the federal Renewable Fuel Standard (RFS). Internationally consistent sustainability standards and practices are needed to inform policy and provide direction and guidance to industry.

\footnotetext{
Trom the time humans first learned to control fire a quarter of a million years ago or more, biomass has served as an important energy resource. Harnessing fire enabled greater control over natural ecosystems and the eventual development of agriculture, which supported increasing populations. As technological sophistication increased, traditional uses of biomass - mostly
}

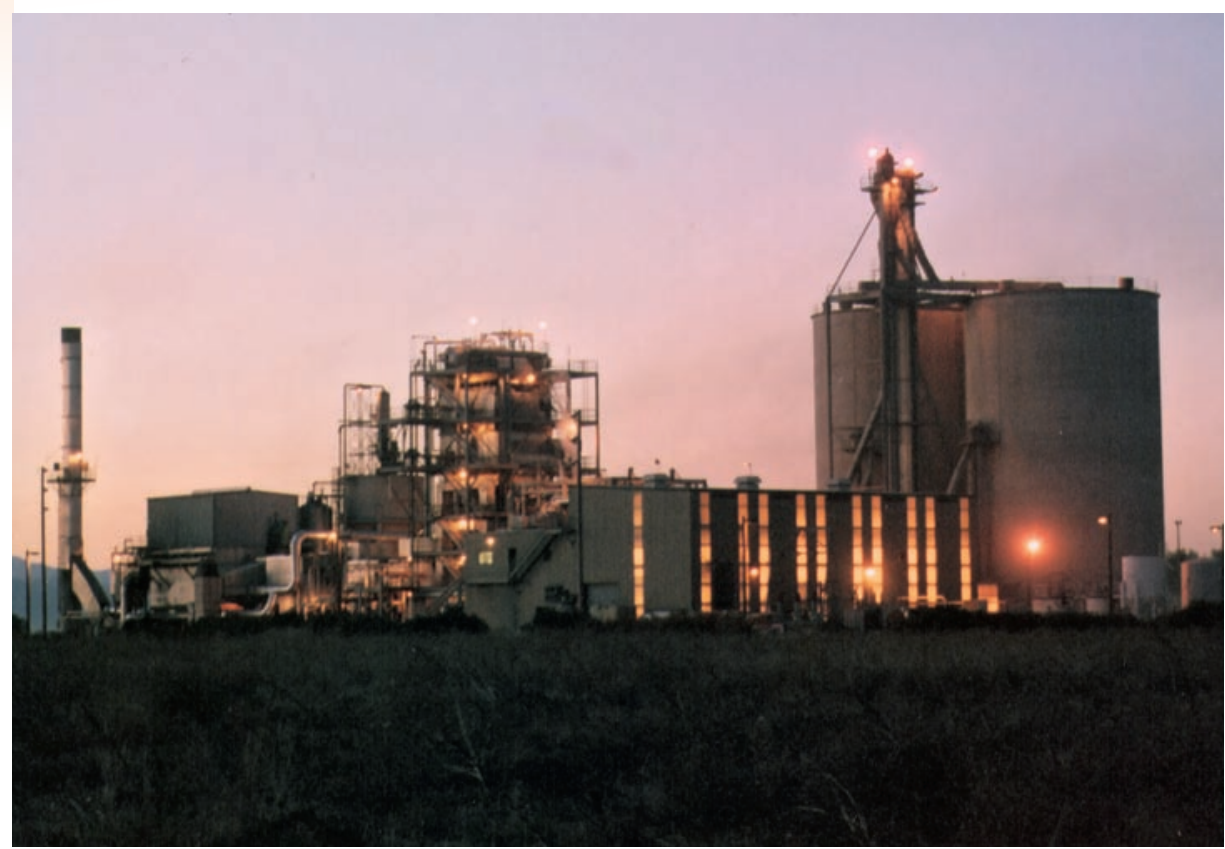

Wadham Energy power plant in Colusa County near Williams generates $\mathbf{2 6 . 5}$ megawatts of electricity from rice hulls, enough to power about 22,000 homes. The plant is one of about 30 operating in California that generate electricity from solid biomass.

inefficient and polluting open fires for land clearing, cooking, heating and lighting - evolved to take greater advantage of this chemically complex resource. Although traditional uses are still widely practiced throughout the world and are often associated with undesirable consequences to health and the environment, more modern, sustainable approaches to utilizing biomass offer significant promise for environmental improvement and economic benefit.

The existence of fossil fuels is principally due to ancient growth and the geological conversion of algae and higher green plants to coal, petroleum and natural gas. As understanding and awareness of how current energy use affects local, regional and global environment and politics, the need for more renewable and sustainable energy supplies and greater energy-use efficiency becomes increasingly apparent, even though huge fossil resources remain especially as coal but also as oil sands, oil shales, methane clathrates and other unconventional sources (Rogner 1997). Replacing all or any large share of the fossil fuel used globally each year - a projected 88 billion barrels of oil equivalent in 2010 (EIA 2009) - will not be easy, but the gains to environmental, economic and social health should be enormous. Solar energy is the primary energy resource of the Earth, and exclusive of breakthroughs in controlled thermonuclear fusion, the quest for more sustainable energy supplies must lead to a highly efficient solar economy including direct solar power conversion as well as indirect methods of wind, hydroelectric power plants, the ocean and biomass.

Biomass is living material. As a feedstock for energy and industrial products, biomass refers to biologically derived renewable materials (but not fossil fuels or materials derived from fossil fuels) (Jenkins 2005). Conventional food, feed and fiber products from agriculture and forestry can also serve as bioenergy feedstocks. Corn, for example, is a staple cereal grain, but is also the primary feedstock for U.S. ethanol production; and cane sugar is the principal source of ethanol in Brazil. The definition of biomass properly excludes plastics, rubber and 
tires found in municipal wastes. As renewable feedstocks replace petrochemicals in the manufacturing of synthetic polymers, these materials will add to the biomass resource.

Coupled with carbon capture and storage (carbon sequestration), biomass production is one of the few methods of removing surplus carbon from the atmosphere while adding to the energy supply. The sustainable use of biomass can reduce reliance on imported forms of energy, particularly petroleum, and provide other ecological and economic benefits. However, in the large-scale production of biofuels envisioned for the United States, Europe and elsewhere, importing biomass feedstock and manufactured biofuels may also become commonplace.

Large questions must be addressed concerning the potential magnitude of the bioenergy supply, renewability of this resource, sustainability of production and utilization practices, feasibility of advanced technologies for converting biomass to fuels and other products, and costs and benefits of a growing industry and commerce built around biomass. Concerns over indirect land-use changes arising from national biofuel policies have recently intensified the debate over the sustainability

\begin{tabular}{|c|c|c|}
\hline \multicolumn{3}{|c|}{$\begin{array}{l}\text { TABLE 1. Estimated annual residue biomass } \\
\text { potential in California } \\
\text { (2005 biomass resource base)* }\end{array}$} \\
\hline Resource & $\begin{array}{c}\text { Gross } \\
\text { production }\end{array}$ & $\begin{array}{r}\text { Feedstock } \\
\text { potential }\end{array}$ \\
\hline \multicolumn{3}{|c|}{.. million dry tons/year . . } \\
\hline Agricultural & 20.9 & 8.8 \\
\hline All animal manures & 10.3 & 3.5 \\
\hline Cattle manure & 8.4 & 3.1 \\
\hline Milk cow manure & 3.9 & 1.9 \\
\hline Orchard and vine & 2.5 & 1.8 \\
\hline Field and seed & 5.0 & 2.2 \\
\hline Vegetable & 1.6 & 0.1 \\
\hline Food processing & 1.5 & 1.2 \\
\hline Forestry & 26.8 & 14.3 \\
\hline Mill residue & 6.2 & 3.3 \\
\hline Forest thinnings & 7.7 & 4.1 \\
\hline Logging slash & 8.0 & 4.3 \\
\hline Shrub & 4.9 & 2.6 \\
\hline Municipal solid waste & 35.2 & 9.1 \\
\hline Biosolids & 0.8 & 0.5 \\
\hline Biomass & 34.4 & 8.6 \\
\hline Total biomass & 82.8 & 32.2 \\
\hline \multicolumn{3}{|c|}{$\begin{array}{l}\text { Source: Gildart et al. } 2006 \text {. } \\
\text { * Does not include landfill gas from municipal waste in } \\
\text { landfills, or biogas from municipal wastewater treatment } \\
\text { facilities. }\end{array}$} \\
\hline
\end{tabular}

of biofuel production and raised questions regarding reductions in global greenhouse-gas emissions (Searchinger et al. 2008) (see page 191).

These concerns have created regulatory uncertainty in formulating California's Low Carbon Fuel Standard (LCFS), although indirect effects are incorporated into recent California Air Resources Board resolution 09-31 relating to LCFS implementation (CARB 2009). As Europe found with bioenergy targets, lack of appropriate sustainability standards can trigger concerns over the longer range impacts of what are intended as environmentally and socially beneficial policies.

Government policies aimed at stimulating biomass markets are often developed with inadequate information to properly assess full life-cycle impacts or evaluate issues of environmental justice and human rights, especially for im-

ported fuels and materials. Formulating comprehensive, internationally consistent, performance-based sustainability standards is central to the larger development of biofuels (Jenkins et al. 2006). Further, the implementation and enforcement of sustainability standards without requiring similar standards for all fuels and energy sources are also likely to create market disparities with unforeseen and potentially undesirable consequences for bioenergy.

\section{Resources and bioenergy potential}

In California, the three primary biomass resources are agricultural residues, forest residues and urban wastes. The state produces an estimated 80 million gross tons of biomass each year,

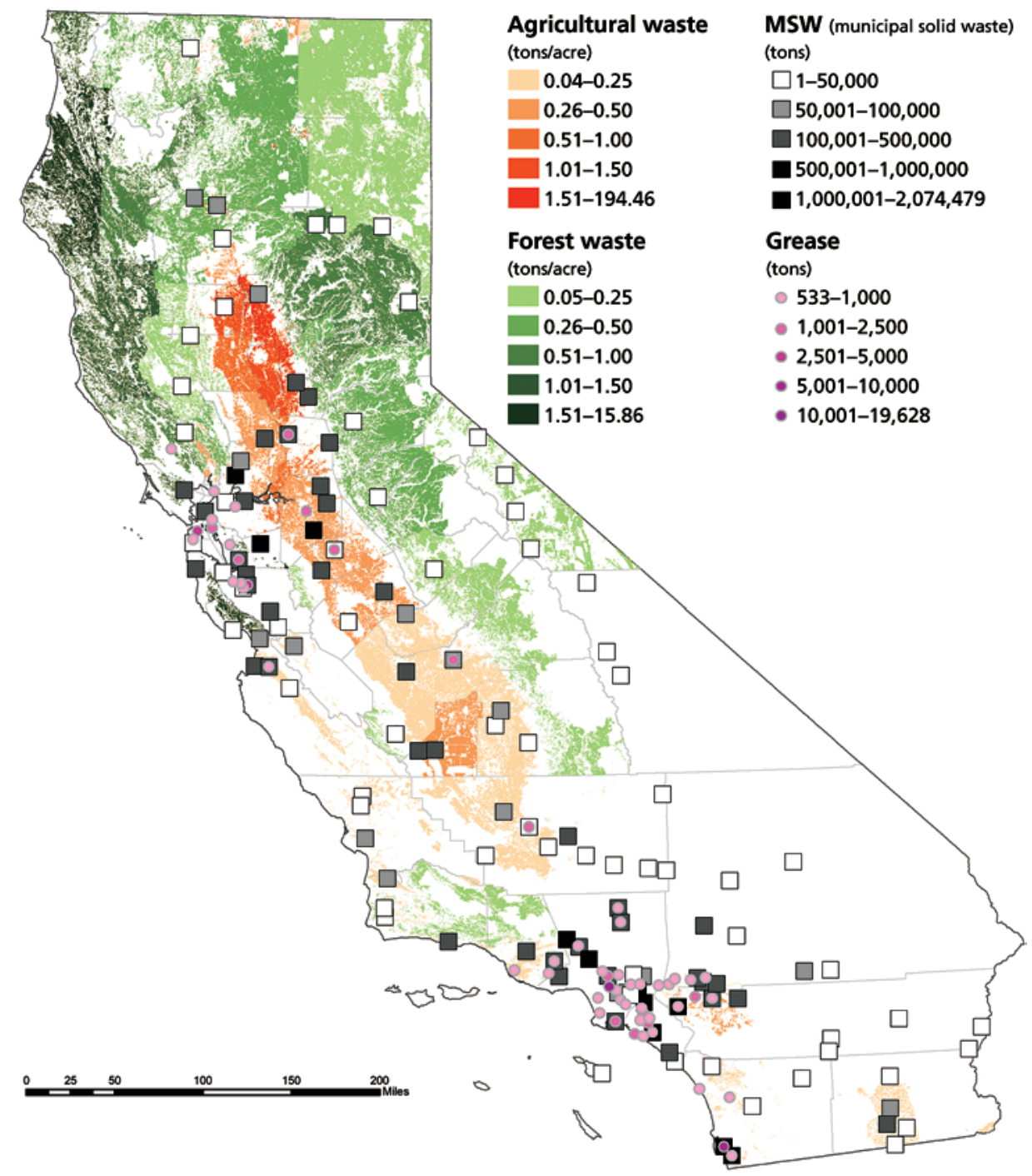

Fig. 1. Distribution of annual biomass resources in California. Source: Tittmann et al. 2008. 
with sustainable feedstock potential of 32 million tons (Gildart et al. 2006) (table 1). Resources are geographically distributed according to the producing regions and urban centers (fig. 1).

Forestry could provide large amounts of biomass if in-forest thinning is increased under more active management to reduce fuel loads and wildfire risks, a subject of public controversy. The amount of biomass available for annual harvesting is uncertain, and other estimates (Strittholt and Tutak 2009) incorporating greater constraints on accessible lands place the resource potential from forest lands at about a third to half of that estimated by the California Department of Forestry and Fire Protection (CDFFP 2005).

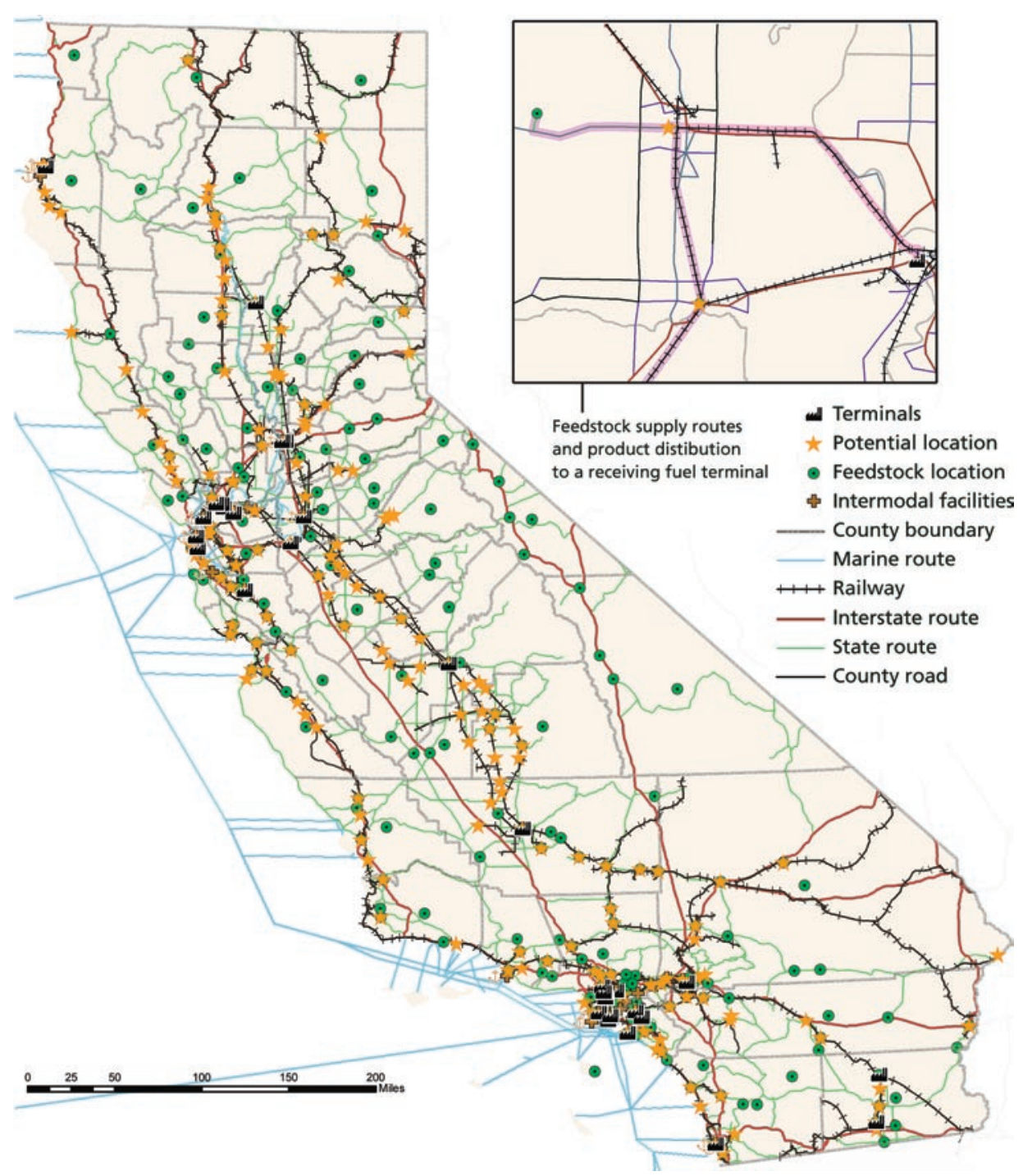

Fig. 2. Potential biorefinery locations in California from a spatially resolved economic optimization model of feedstocks, energy markets, and supply and distribution infrastructure. Source: Tittmann et al. 2008.
The urban sector contributes an estimated 35 million tons of biomass, mostly from municipal solid waste but wastewater treatment. At present, about equal amounts of municipal solid waste are sent for disposal or diverted to other uses such as composting, recycling and biomass conversion. More than a million tons of urban wood fuel - mostly construction waste - are already used in biomass power plants around the state.

Nationwide, more than a billion tons of biomass could be sustainably produced from agriculture and sufficient to supply roughly a third of transportation fuel demand, and possibly more with future improvements in also smaller amounts of biosolids from forestry yearly (Perlack et al. 2005), transportation efficiency. Worldwide, estimates suggest a sustainable production about five times that of the United States from current sources (Parikka 2004).

Additional biomass could come from purpose-grown crops such as switchgrass, Miscanthus, oilseeds, algae and many others, but the extent to which these can contribute to overall supply is still speculative. Water is a critical issue for energy-crop production, and California's high-value agricultural commodities may be less prone to crop shifting for bioenergy than other areas of the United States, such as the Midwest Corn Belt. Energy crops may aid in remediating salt-affected and drainage-impaired soils in the San Joaquin Valley and elsewhere (Jenkins 2005; Stapleton and Banuelos 2009). Intensively studied since at least the 1950s, industrial algae production could also significantly expand biomass resources due to high growth rates and yields (estimated maximum yields of 5,000 to 15,000 gallons of biofuel per acre per year) and potentially use drainage water, brackish water, wastewater and seawater, but future production levels and costs also remain highly speculative (Sheehan et al. 1998).

\section{Modeling biomass quantities}

The quantity of biomass that can be harvested and used economically is of critical importance. This was recently estimated using an economic optimization model coupled with a spatially explicit geographic information system (GIS) of the distribution of biomass resources, roads and other transportation infrastructure, and regional energy demand throughout California (fig. 2) (Tittmann et al. 2008). The modeling framework was initially developed as part of a study of biofuel production in the western United States (Parker et al. 2008), and has now been applied with greater resolution in California and expanded to include the entire United States. Depending on the market scenario and the extent that forest resources contribute, the estimated biomass resource that can be economically recovered in California varies between about 18 and 25 million dry tons per year at biofuel prices from $\$ 2.20$ to $\$ 4.00$ 
per gallon of gasoline equivalent (gge), excluding corn imports but including in-state waste oils and fats.

The results are sensitive to the value of heat in combined heat and power (CHP) operations, such as the use of power-plant waste heat for industrial uses. Biogas potential from landfills, animal manures and wastewater treatment is not included, but constitutes a resource equivalent to another 5 or 6 million tons of biomass beyond the 32 million of table 1 . The model shows that at prices below $\$ 1.50$ per gge, electricity markets provide demand for the lowest-cost biomass resources - about 5 million tons and roughly equivalent to current demand by the California biomass power sector. Above this price, the model predicts demand increasing rapidly for transportation biofuels until nearly full resource utilization at $\$ 2.50$ per gge. The recent economic downturn has essentially collapsed the cornethanol industry in California due to high corn-feedstock prices and low ethanol market prices. Stabilizing energy prices to reduce fuel-price volatility will be an important near-term consideration for state and national policy.

\section{Other energy sources}

Projected biomass resources in California can support increasing electricity generation and the production of renewable natural gas (biomethane), liquid biofuels and eventually, hydrogen. Total production in these categories from in-state biomass resources might exceed the energy equivalent of 3 billion gallons of gasoline each year (fig. 3) (Jenkins et al. 2006), or about $6 \%$ of total statewide energy demand. Energy potentials are quite large within any one category of energy demand (table 2), but multiple uses are likely to compete for resources in the future. California's current annual harvest of starch and sugar crops alone would be sufficient to produce more than 300 million gallons of ethanol (230 million gge) (Williams 2007). For economic reasons, a complete shift of grain and sugar supplies to energy markets is not likely to occur. Statewide lignocellulosic ethanol potential from agricultural, forestry and urban residues is about 1.2 billion gge per year, and with additions of bio-

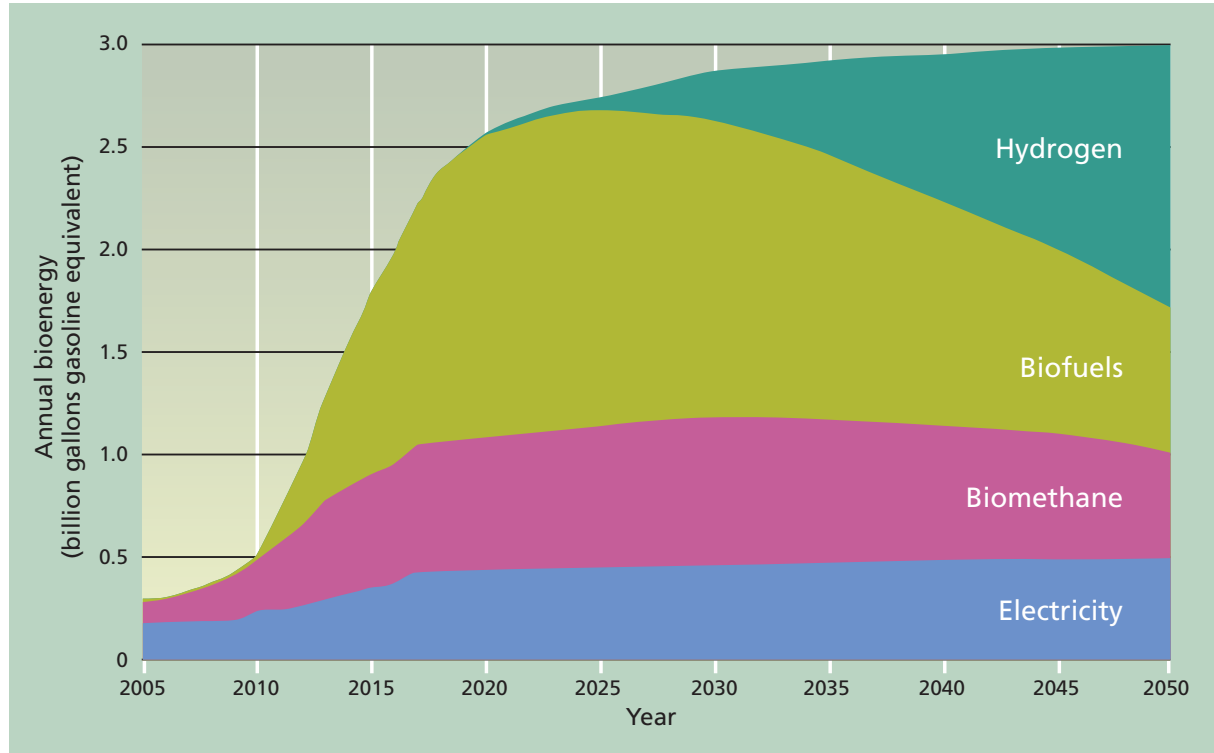

Fig. 3. Speculative development scenario for bioenergy in California. Source: Jenkins et al. 2006.

TABLE 2. Energy potentials from available California biomass feedstocks by energy category (2005 biomass resource base)

\begin{tabular}{|c|c|c|c|}
\hline Category* & Biomass & Energy in productt & Total capacity $¥$ \\
\hline & million dry tons/year & trillion Btulyear & \\
\hline $\begin{array}{l}\text { Electricity } \\
\text { CHP heat }\end{array}$ & 32 & $\begin{array}{c}118 \text { (35 TWh/yr) } \\
230\end{array}$ & $\begin{array}{l}\text { 4,650 } \mathrm{MW}_{\mathrm{e}} \\
9,050 \mathrm{MW}_{\mathrm{t}}\end{array}$ \\
\hline Heat & 32 & 350 & $11,700 \mathrm{MW}_{\mathrm{t}}$ \\
\hline Biochemical biofuel & 32 & 188 & 1.5 billion gge/yr \\
\hline Thermochemical biofuel & 27 & 250 & 1.9 billion gge/yr \\
\hline Biomethane & 5 & 100 & 0.8 billion gge/yr \\
\hline Hydrogen (bio + thermal) & 32 & 305 & 2.1 billion gge/yr \\
\hline $\begin{array}{l}\text { Sources: Jenkins et al. 2006; } \\
\text { * CHP = combined heat and po } \\
\text { Thermochemical conversion is } \\
\text { derived from anaerobic diges } \\
\text { † TWh = terawatt-hours (billion } \\
\text { ₹ MW }=\text { megawatt electric; MV } \\
\text { based on assumed low yields } \\
\text { moisture content. }\end{array}$ & $\begin{array}{l}\text { (coms et al. } 2007 . \\
\text { sed on gasification followe } \\
\text { of biomass. } \\
\text { h). } \\
\text { megawatt thermal (heat); } \\
\text { dedicated crops. Tonnage f }\end{array}$ & $\begin{array}{l}\text { l conversion is based on } \\
\text { by Fischer-Tropsch synth }\end{array}$ & $\begin{array}{l}\text { tion to ethanol. } \\
\text { nethane is methane }\end{array}$ \\
\hline
\end{tabular}

TABLE 3. California annual lignocellulosic ethanol potential

\begin{tabular}{lccc}
\hline Biomass source & Potential feedstock & \multicolumn{2}{c}{ Potential ethanol } \\
\hline & million dry tons & million gallons & million gge* \\
Field and seed & 2.3 & 160 & 105 \\
Orchard and vine & 1.8 & 125 & 83 \\
Landfilled mixed paper & 4.0 & 320 & 213 \\
Landfilled wood and green waste with & 2.7 & 216 & 144 \\
$\quad$ alternative daily cover (ADC) & & 990 & 1,205 \\
Forest thinnings & 14.2 & 1,814 & 400 \\
\hline Totals - current California & 24.9 & 600 & 900 \\
\hline 1.5 million acres dedicated energy crop & & 1,350 & 1,605 \\
Low yield (5 dry tons/acre, 80 gallons/ton) & 7.5 & & 2,105 \\
High yield (9 dry tons/acre, 100 gallons/ton) & 13.5 & 2,414 & \\
State potentials & & 3,164 & \\
$\quad$ Low yield & 32 & & \\
High yield & 38 & & \\
\hline Source: Williams et al. 2007. & & & \\
* gge = gallon of gasoline equivalent. & & & \\
\end{tabular}



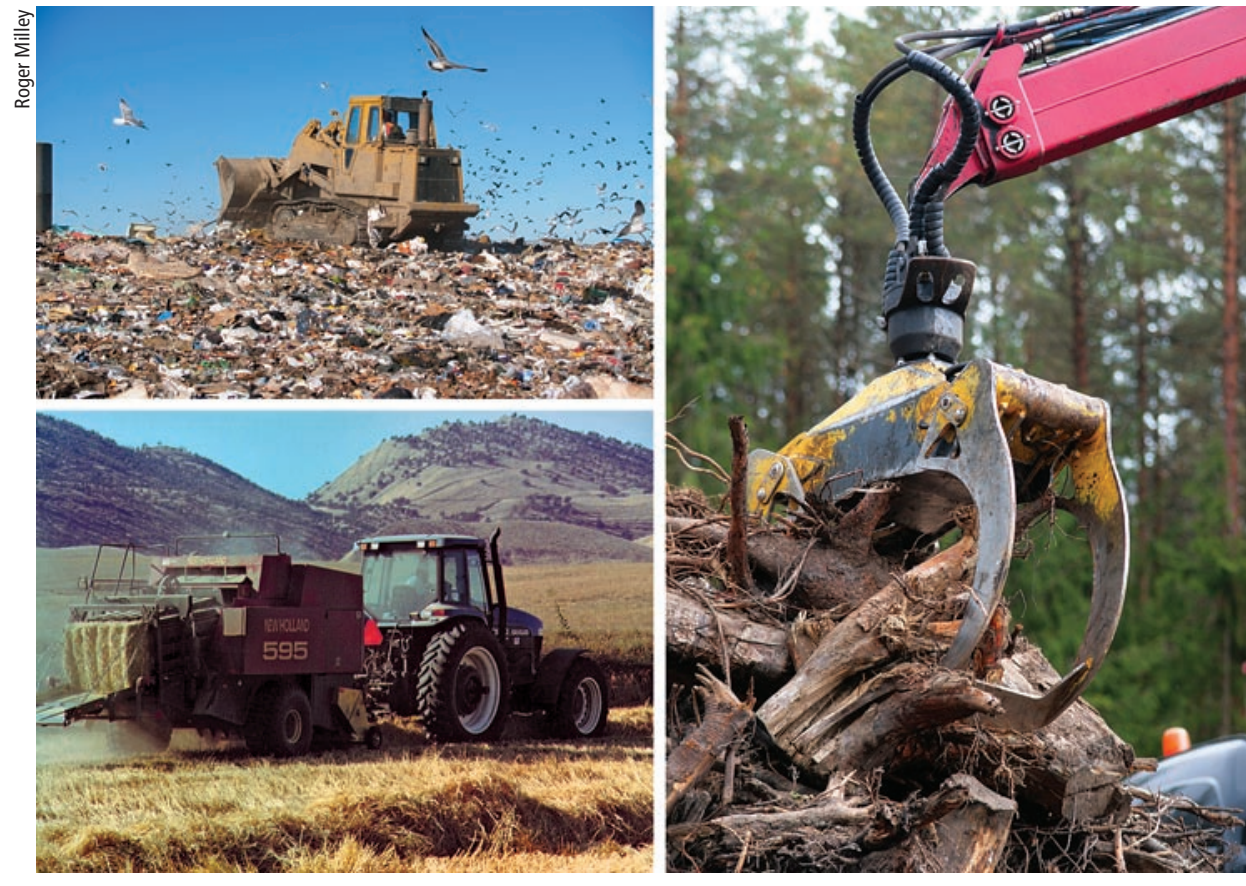

The three main existing biomass resources in California are, top left, municipal waste, bottom left, agricultural residues and, center, forestry residues.

energy crops on marginal lands, could approach 2 billion gge per year (table 3) (Williams 2007).

In addition to ethanol, other energy types might emerge in competition with liquid fuels for the transportation market, particularly electricity and hydrogen. The demand for electricity from biomass could be much larger than speculated if advances continue in hybrid-electric and battery-electric vehicle design. High-efficiency clean diesel technologies could also shift production capacity away from gasoline substitutes. High-efficiency vehicles that are nearing commercial introduction achieve substantially better fuel economy than the new U.S. 35-mile-pergallon corporate average fuel economy (CAFE) standard for 2020 under the Energy Independence and Security Act (EISA) of 2007, although similar highefficiency gasoline technologies are also in development.

Imports of feedstocks and finished biofuels will further increase the share of the state's energy supplied from biomass, but careful attention must be directed toward the sustainability of production, especially in areas outside

\begin{tabular}{|c|c|c|c|}
\hline \multirow[b]{2}{*}{ Fuel type } & \multicolumn{3}{|c|}{ Conversion process } \\
\hline & Thermochemical & Biochemical & Physiochemical \\
\hline Solid & $\begin{array}{l}\text { Biomass } \\
\text { Chars } \\
\text { Charcoal }\end{array}$ & Biosolids & $\begin{array}{l}\text { Densified biomass } \\
\text { Other processed fuels }\end{array}$ \\
\hline Liquid & $\begin{array}{l}\text { Methanol } \\
\text { Biomass-to-liquids (BTL) } \\
\text { Renewable diesels, biogasolines, } \\
\text { other hydrocarbons and } \\
\text { oxygenated hydrocarbons } \\
\text { Ethanol } \\
\text { Mixed alcohols } \\
\text { Dimethyl ether } \\
\text { Bio-oils (pyrolysis oils) }\end{array}$ & $\begin{array}{l}\text { Ethanol } \\
\text { Butanol } \\
\text { Other alcohols } \\
\text { Mixed alcohols } \\
\text { Liquified biomethane (LNG) } \\
\text { [Bio]gas-to-liquids (GTL) }\end{array}$ & $\begin{array}{l}\text { Biodiesel (esters from } \\
\text { plant, algal and yeast } \\
\text { oils) } \\
\text { Alkanes (catalytic) }\end{array}$ \\
\hline Gas & $\begin{array}{l}\text { Producer gas } \\
\text { Synthesis gas (syngas) } \\
\text { Substitute natural gas (SNG) } \\
\text { Hydrogen }\end{array}$ & $\begin{array}{l}\text { Biogas } \\
\text { Biomethane } \\
\text { Compressed biomethane } \\
\text { (CNG) } \\
\text { Hydrogen }\end{array}$ & \\
\hline
\end{tabular}

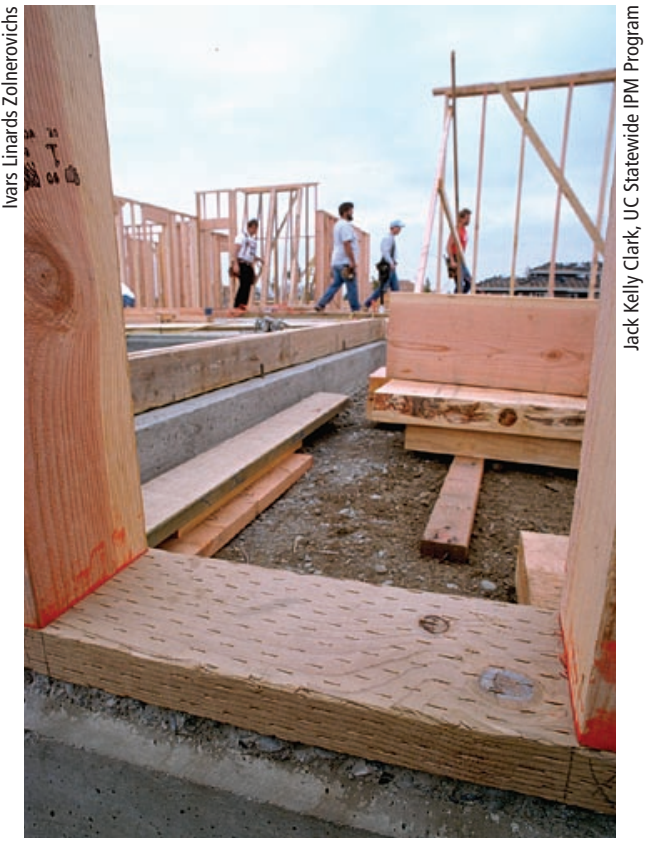

More than a million tons of urban wood fuel, mostly construction waste, are currently being burned in biomass power plants statewide.

the state. Nearly all 950 million gallons of ethanol used in California in gasoline blends is imported from other states and countries. Although in-state ethanol biorefining capacity increased to above 100 million gallons per year in 2007 , changing economic conditions resulted in industry suspensions of existing operations and new project development of facilities based on imported corn. California is therefore not likely to meet the target of $20 \%$ in-state production of biofuel by 2010 under the state's bioenergy action plan.

\section{Feedstock properties}

Feedstock properties also influence the cost and energy conversion potential of the resource (table 4). High moisture contents, above about $50 \%$ for example, tend to favor systems where feedstock drying is not required. Much of the animal manure, vegetable, food and municipal green waste is high moisture at the collection point and is often considered for anaerobic digestion, ethanol fermentation or other biochemical conversion. Of the 30 million tons of biomass that California considers technically available for conversion, at least $20 \%$ falls into this high moisture category.

Moisture is not the only property of importance, however, and feedstocks vary in composition (Jenkins 

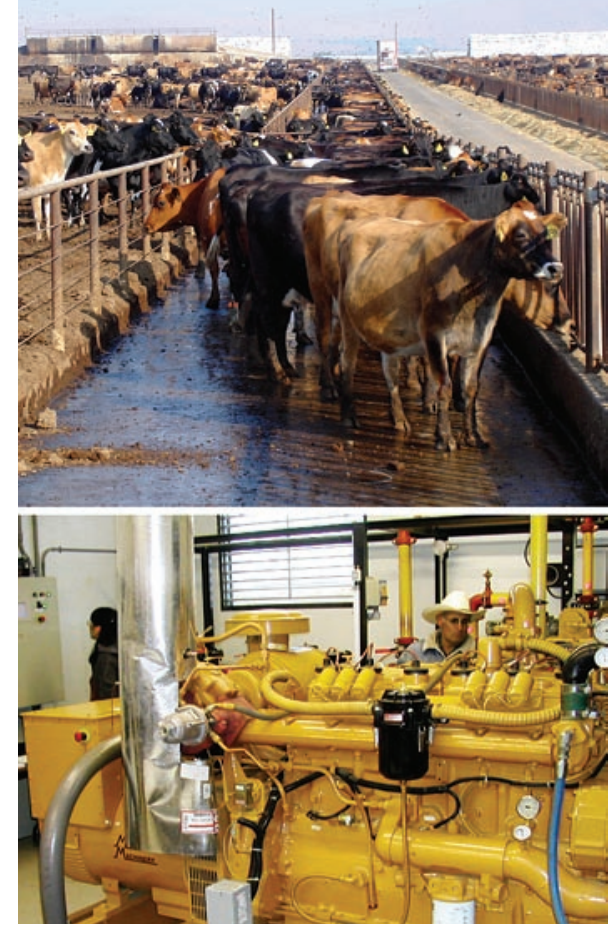

Top, manure from dairy cattle is used as a feedstock for anaerobic digestion to produce biogas (primarily methane and carbon dioxide), which, above, generates electricity at the Castelanelli Dairy in Lodi.

et al. 1998). Factors that influence the type and design of conversion facilities include the proportions of sugars, starches and lipids; structural components including cellulose, hemicellulose and lignin; inorganic materials in ash; and heavy-metal concentrations. Energy-crop sugar cane trials in the Imperial Valley produced total biomass yields of 65 wet tons per acre per year, with sugar yields averaging $15 \%$, or close to 10 tons per acre per year suitable for ethanol fermentation (Shaffer et al. 2009). Bagasse, the mostly lignocellulosic residue remaining following sugar extraction, accounts for another $18 \%$ of the crop, or roughly 11 tons of dry matter per acre per year, although as it leaves the mills the moisture content is about $50 \%$. Bagasse is commonly burned for steam and power generation to support sugar mill or biorefinery operations and for export, but it could also be converted biochemically to increase ethanol yields.

\section{Energy uses for biomass}

The complex chemical structure of biomass gives it a tremendous range of uses, but also presents challenges for producing higher-value chemicals and products. Biomass can substitute for fossil resources in virtually all applications, although the various processes

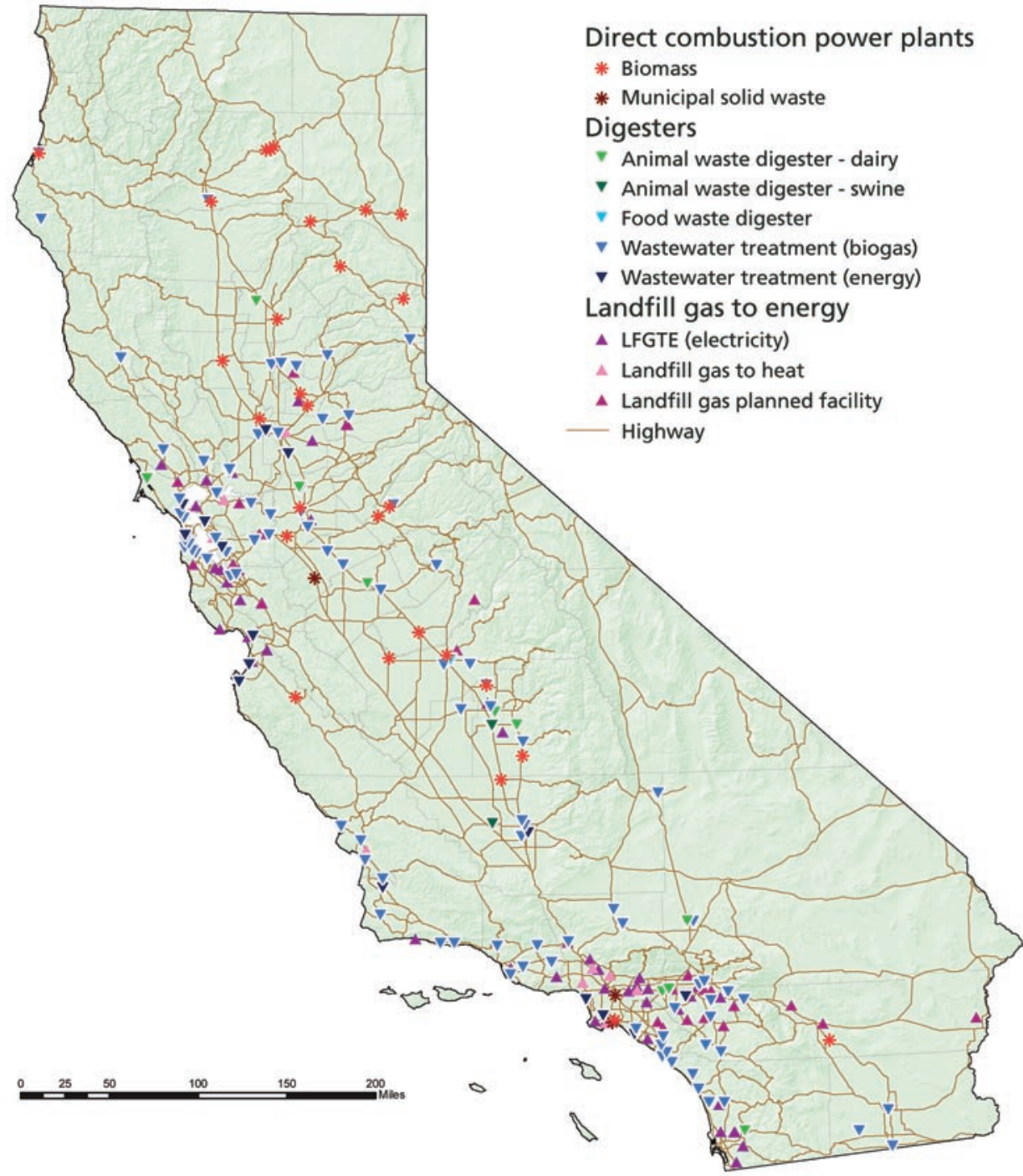

Fig. 4. Biomass power generation facilities in California. Source: Williams et al. 2007.

are not fully commercialized. Feedstock characteristics influence the technology designed to use it. Ethanol produced from starch and sugar and biodiesel from fat, oil and grease involve wellknown commercial processes. The conversion of lignocellulosic biomass such as wood and grasses to high-quality liquid fuels is still precommercial, with large-scale demonstrations under development throughout the United States.

Electricity. In California, electricitygenerating capacity from biomass currently exceeds 1,100 megawatts from solid-fuel, landfill gas and digester gas facilities across the state (fig. 4), and annual electrical energy from biomass exceeds $2 \%$ of state demand. The prospects for electricity from biomass and other renewable sources were recently enhanced by the state's Renewable Portfolio Standard (RPS), which calls for $20 \%$ of the state's retail electricity to come from renewable resources by the end of 2010 (California Public Resources Code, Section 25740) and 33\% by 2020. The California Public Utilities Commission (CPUC) currently projects that the 2010 target may not actually be met until around 2013.

The California RPS is resourceneutral and sets no specific target levels or quotas for power generation from particular renewable energy sources. The governor's 2006 Executive Order S-06-06, however, calls for $20 \%$ of RPS elctricity to come from biomass. Competition from wind and geothermal sources has so far resulted in biomass lagging behind this goal. 


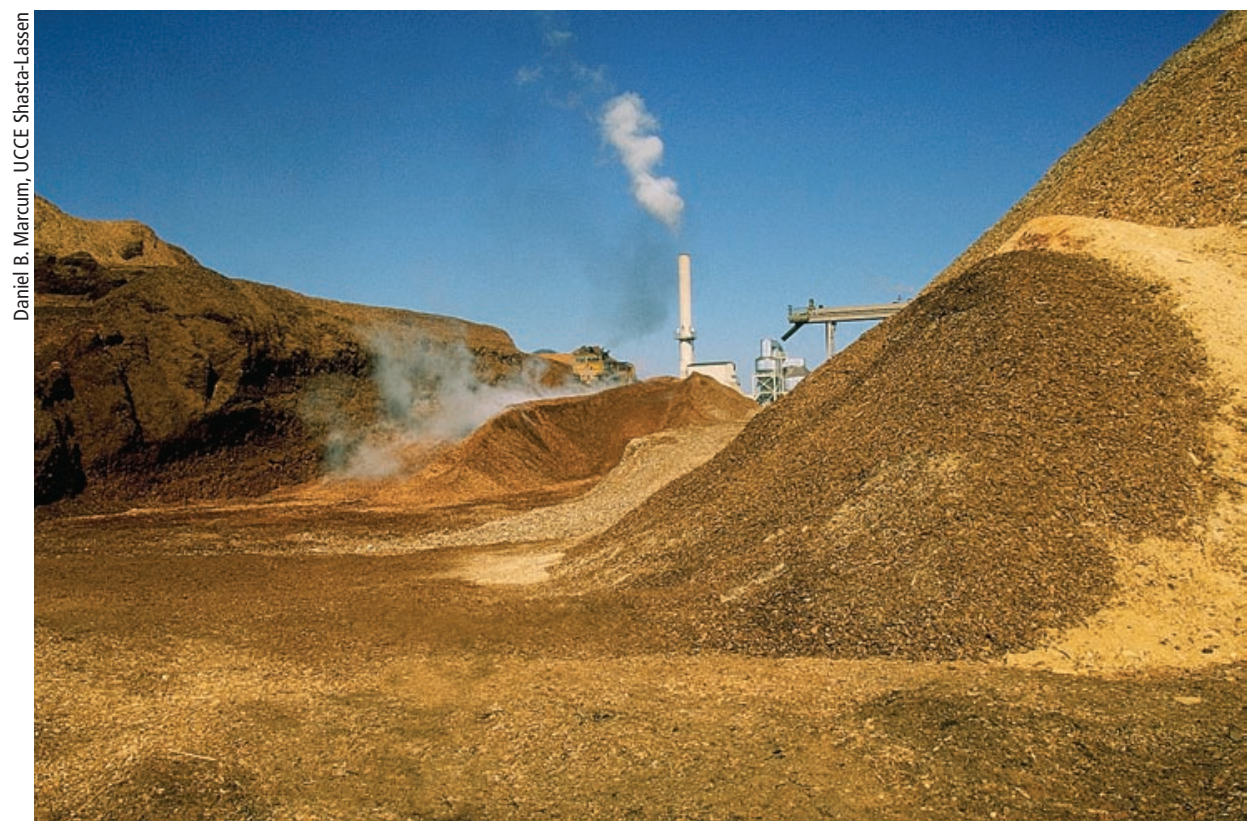

An estimated 14 million dry tons of forestry residues could be sustainably processed in California each year for energy. Above, large piles of wood chips are mixed together before being burned in the distant power plant.

Biogas. The California Energy Commission administers the Dairy Power Production Program (DPPP), created by the California legislature during the state's 2000 and 2001 electricity crisis. Demonstration manure digester projects were installed to generate close to 3 megawatts, but air-quality concerns, mostly over nitrogen-oxide emissions, now limit capacity, and some generators have ceased operations. Upgrading digester gas to meet or exceed natural-gas-pipeline quality standards provides another market,

\section{The sustainable use of biomass can reduce reliance on imported forms of energy, particularly petroleum, and provide other ecological and economic benefits.}

and at least one project is now in operation. One of the dairies participating in the DPPP is now dual-fueling its large milk-delivery trucks with compressed biomethane from a digester. Increasing electricity demand from the transportation sector may also drive improvements in generation technology through improved system efficiency.

Liquid and gas fuels. Hydrocarbon liquids similar to gasoline and diesel fuels can be produced by thermochemical methods - principally gasification and pyrolysis of biomass by heating under limited oxygen conditions, with secondary refining - through FischerTropsch (FT) synthesis, hydrotreating and other chemical-catalytic techniques. The resulting liquid fuels include methanol, ethanol, mixed alcohols, dimethylether (DME), bio-oils and fuel gases that include synthesis gas (or syngas, a mixture of carbon monoxide and hydrogen with other gases), substitute natural gas (SNG) and hydrogen.

Biochemical methods using microbial conversion in fermentation and anaerobic digestion can produce ethanol, butanol, methane, hydrogen and other fuels. Both landfill gas and digester gas are produced through the natural anaerobic decomposition of the degradable fraction of biomass. The resulting biogas consists principally of methane and carbon dioxide with smaller concentrations of hydrogen sulfide and other trace gases. Lignocellulosic biomass can be converted to ethanol via the pretreatment and hydrolysis of cellulose and hemicellulose to release sugars for fermentation. The lignin fraction is typically considered for use as boiler fuel for steam and power generation in biorefinery operations, although lignin can also be thermochemically upgraded into fuels, and research is continuing on biochemical pathways for converting lignin to biofuel (see page 178). Compared to ethanol, butanol is at present more compatible in the existing pipeline and transportation infrastructure but is still developmental as a fuel.

Biodiesel. Conventional biodiesel is produced through a base-catalyzed transesterification reaction in which a lipid such as a vegetable oil or animal fat is reacted with an alcohol, generally methanol or ethanol. The oil-alcohol reaction is catalyzed using sodium hydroxide or potassium hydroxide to produce a fatty-acid methyl ester, also known as FAME. In the United States, soybeans are the primary feedstock, and in Europe, rapeseed. Glycerol is a coproduct of the esterification, and expanding biodiesel markets will require finding new uses for glycerol. Biodiesel has lower viscosity compared to the original feedstock oil, and as a result has improved atomization and burning characteristics in diesel engines. Biodiesel can be used neat $(100 \%$ biodiesel or B100) or blended with regular diesel fuel. High feedstock costs are now restricting growth in biodiesel production capacity. It can be produced at lower cost from waste fats, oils and greases such as used fryer oil, but the total resource potential is small compared to fuel demand. Vegetable oils and biodiesel can be deoxygenated to produce upgraded hydrocarbon liquids that are more like diesel fuel, although this level of refining adds to the cost.

\section{Greenhouse-gas reductions}

New federal energy legislation mandates substantial increases in the amount of biofuel produced and used in the United States. The nation's Renewable Fuel Standard (RFS) calls for producing 36 billion gallons by 2022 . To qualify under the standard, reductions in life-cycle greenhouse-gas emissions must accompany fuel production within defined biofuel categories.

The U.S. Environmental Protection Agency (EPA) estimates that corn ethanol production using coal or natural gas to supply the process energy 
in biorefineries may have difficulty meeting the RFS for a $20 \%$ life-cycle reduction in greenhouse-gas emissions relative to gasoline (fig. 5), although an option to reduce the requirement to $10 \%$ might qualify facilities using natural gas. Ethanol from corn using biomass for process energy exceeds the standard, as does sugar cane ethanol. Biodiesel from soybean oil does not meet the mandated $50 \%$ reduction in greenhouse-gas emissions, a particular concern for the industry as soy diesel constitutes the majority of biodiesel presently produced in the United States. Biodiesel from waste lipids readily complies. Ethanol production from lignocellulosic feedstocks such as switchgrass and corn stalks exceeds the standard of $60 \%$ greenhouse-gas reduction for cellulosic fuels.

California's LCFS requires that by 2020 the state achieve a $10 \%$ reduction in life-cycle carbon intensity (greenhouse-gas emissions) of transportation fuels relative to the 2010 baseline. Similar to the federal RFS, estimates by the California Air Resources Board show coal-fired corn ethanol production exceeding the carbon intensity of gasoline when indirect effects from land conversion elsewhere in the world are included. The magnitude of the indirect carbon intensity assigned to different biofuels has been a matter of debate and will receive continuing attention and research.

\section{Logistics and economics}

From raw materials to finished product delivered into final demand, bioenergy systems invariably involve extensive logistical supply chains. For purpose-grown energy crops, this includes growing and harvesting as well as transportation, storage, processing, conversion, product distribution, sale and use. These operations can be combined to optimize the system design either by minimizing costs or maximizing profits. In addition, economies of scale in capital costs for the biorefinery, combined with increasing feedstock delivery costs as facility size or production capacity increases, often lead to an optimal facility size. Opportunities exist for greater integration of heat, power and fuel production in distributed generation and advanced biorefinery systems.

Feedstock acquisition costs vary depending on type, location, distribution and alternative uses. In most cases, waste-to-energy facilities are able to charge a disposal or tipping fee for feedstocks such as mixed municipal solid wastes, thereby accruing additional revenue to offset facility capital and operating expenses. Such disposal

fees now range from about $\$ 50$ to $\$ 60$ per ton in California.

As competition increases for these resources, this trend may reverse. Costs for collecting, transporting and storing agricultural residues in bioenergy applications are typically in the range of $\$ 25$ to $\$ 50$ per dry ton. Biomass from forest thinning and stand improvement commonly costs $\$ 30$ to $\$ 50$ per ton at roadside and an additional

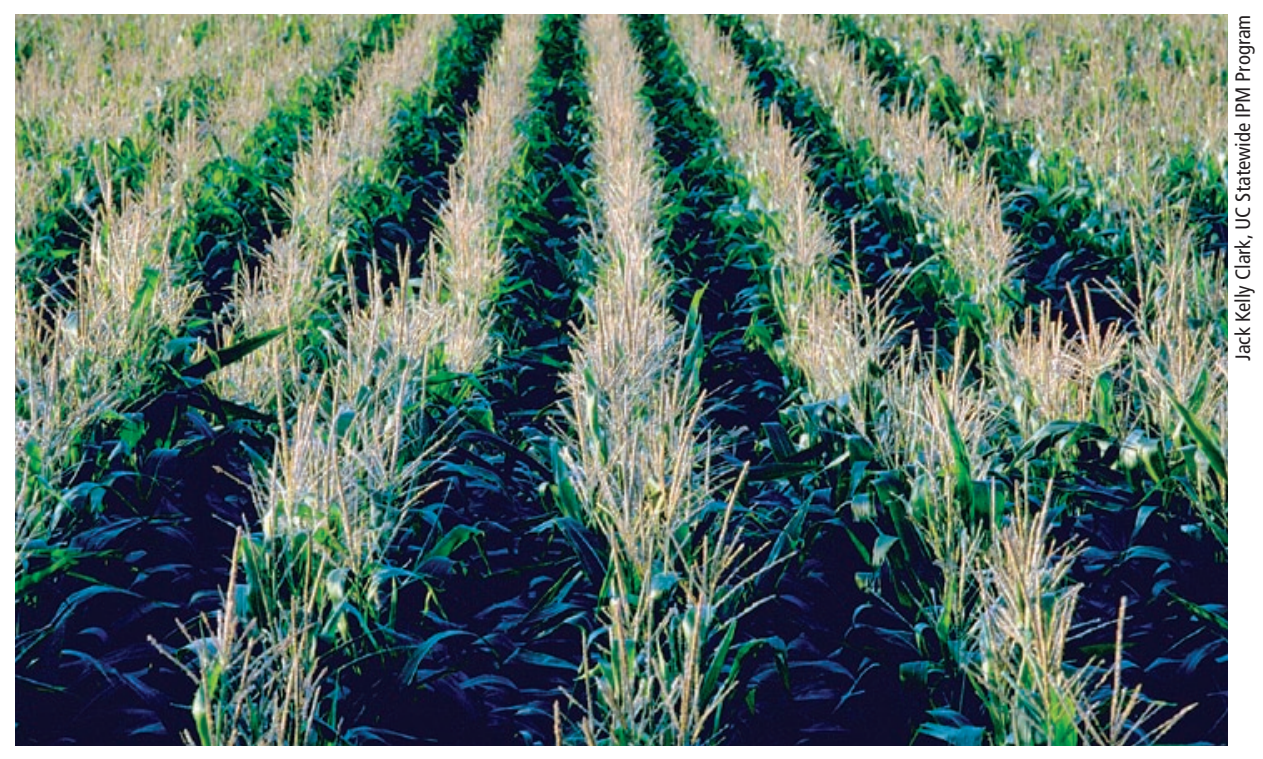

The most common biofuel sources in the United States are corn (shown), which is fermented into ethanol and blended into gasoline, and soybeans, which are converted to biodiesel. However, corn- and soybean-based biofuels may not meet the federal Renewable Fuel Standard for reducing greenhouse-gas emissions.

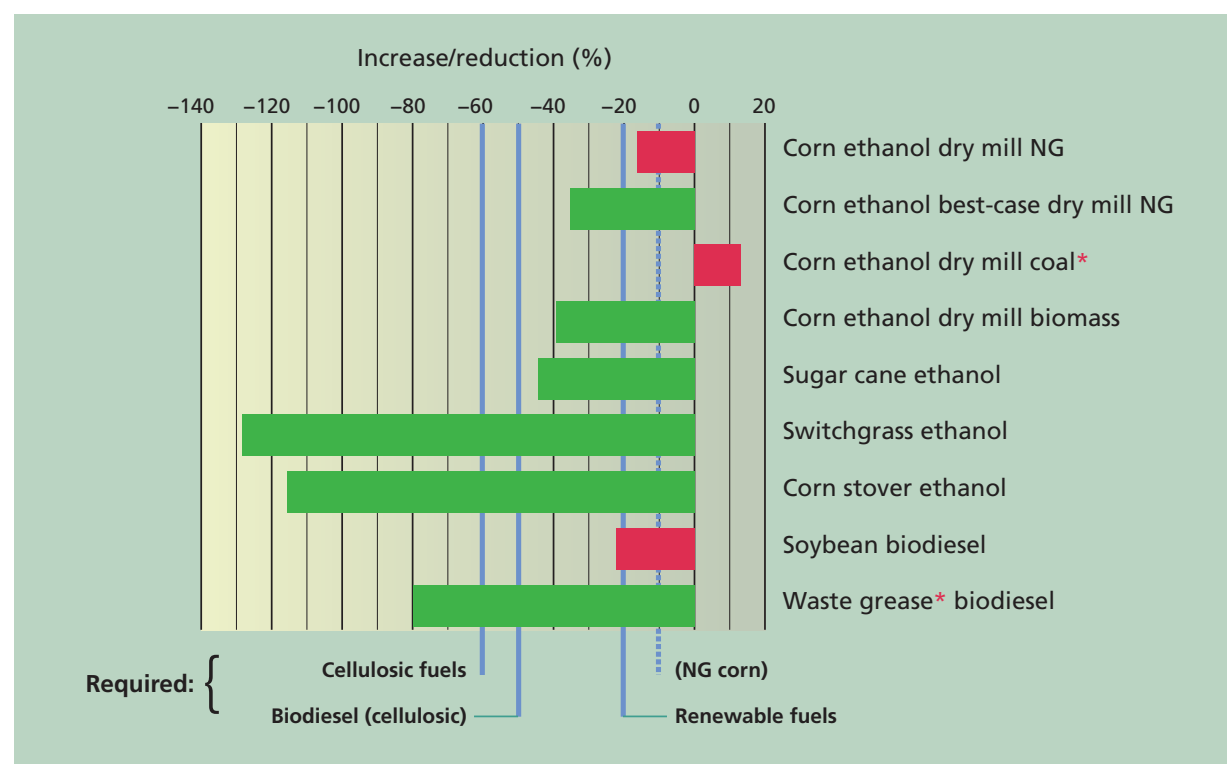

Fig. 5. Estimated life-cycle greenhouse-gas-emission reductions for different biofuel pathways. Red bars show pathways that are estimated not to meet federal reduction requirements under the Renewable Fuel Standard (vertical lines), green bars do. Dry mill = corn-milling technique used in the production of ethanol from corn; NG = natural gas. Source: US EPA 2009. 

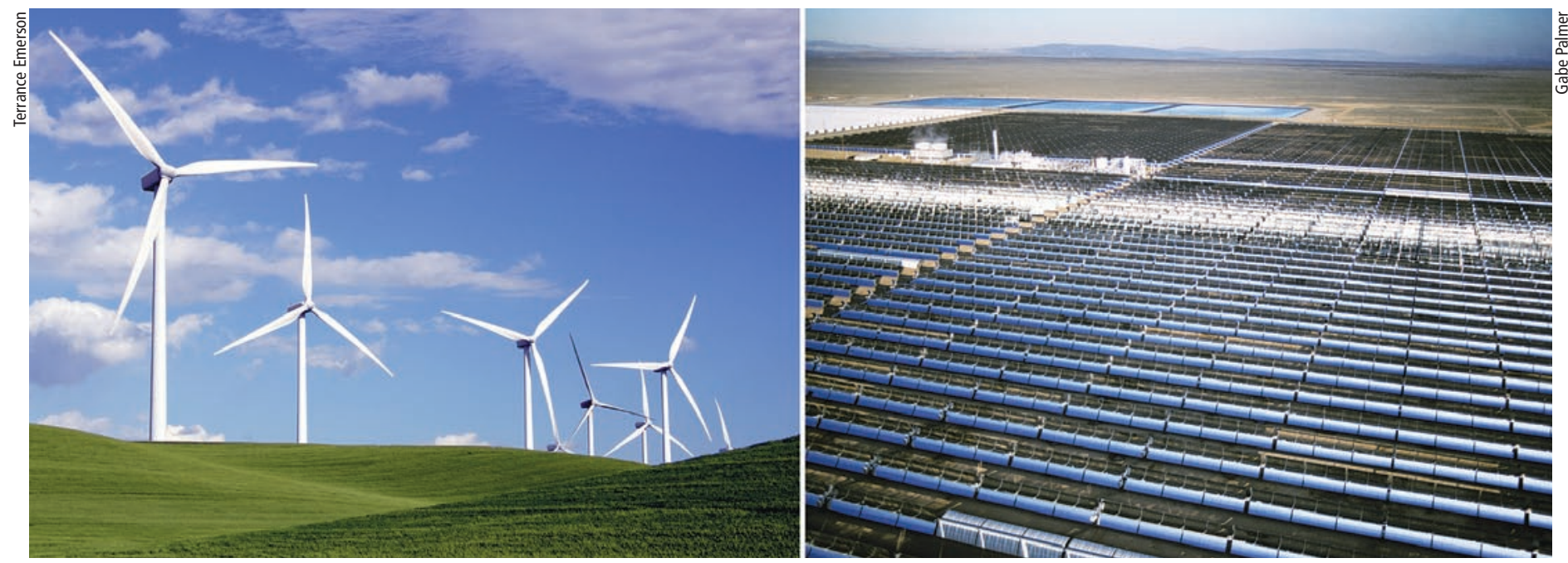

Energy from the sun can be converted into, right, solar power. The search for more sustainable energy sources should include direct solar conversion as well as indirect methods such as, left, wind, hydroelectric and biomass.

$\$ 0.20$ to $\$ 0.60$ per mile per ton to deliver. Collection costs are higher for smaller trees and on steeper slopes. The development of small-tree-specific equipment may reduce these costs. Intermediate processing such as pelleting, pyrolysis (breaking down using heat) and alcohol synthesis using portable equipment or at satellite facilities has been proposed to reduce transportation costs, although these applications appear to be most economically advantageous beyond about 200 miles.

Component costs depend on yields (tons per acre), equipment capacities (tons handled per hour), type of processing and packaging employed (loose, baled, chopped, chipped, densified), mode of transportation (truck, rail, barge, pipeline), type of storage (short-term, long-term, tarped, permanent structure) and associated input costs (labor, fuel, materials). Costs for purpose-grown energy crops typically range from about $\$ 25$ to more than $\$ 115$ per dry ton. The total cost of energy-crop biomass includes growing the crop, which is generally not included for agricultural and forest residues. For example, feedstock costs for switchgrass in the U.S. Midwest are estimated to range from $\$ 30$ to $\$ 70$ per ton, of which $40 \%$ is attributed to production prior to harvesting (Wright et al. 2000).

Feedstock costs have significant impacts on the cost of finished product from conversion facilities. At conversion efficiencies of $20 \%$ for conventional biomass-fueled, steam-cycle power generation, each increment of $\$ 10$ per dry ton in feedstock cost adds approximately $\$ 0.01$ per kilowatt-hour (kWh) to the cost of electricity. Total electricity costs from biomass currently range from $\$ 0.06$ to $\$ 0.10$ per $\mathrm{kWh}$ for new power plants. Capacity payments under some power sales contracts provide additional revenue (typically about $\$ 0.02$ per kWh) to energy sales. Advanced power plants operating at higher efficiencies, such as biomass integrated gasifier combined cycle (BIGCC) technologies, might realize costs ranging from $\$ 0.05$ to $\$ 0.07$ per $\mathrm{kWh}$. Where on-site or nearby heat or cooling demand exists and plants can operate in cogeneration or polygeneration mode, significant economic incentives exist if waste heat utilization can offset natural gas, propane or other fuel purchases.

On an energy basis, corn prices of $\$ 4$ per bushel (\$143 per ton) equate to about $\$ 8$ per million British thermal units ( $\$ 8$ per MMBtu), roughly equivalent to crude oil at $\$ 46$ per barrel. At the U.S. average ethanol yield from corn of 96 gallons per ton, this corn price adds $\$ 1.49$ per gallon to the cost of ethanol, similar to feedstock costs for sugar cane or sugarbeets. The heating value of ethanol is lower than gasoline, so the feedstock cost is equivalent to about $\$ 2.33$ per gge without accounting for engine optimization on the different fuels (the higher octane of ethanol offsets the energy penalty for optimized engines). Ethanol production costs based on corn dry milling are about $\$ 0.52$ per gallon, exclusive of feedstock costs (Shapouri and Salassi 2006).

Without coproduct credits (e.g., distiller grains for animal feed) and federal production incentives, corn ethanol costs are close to $\$ 3$ per gge. Coproduct values and blender's credits reduce this cost by roughly $\$ 1$ per gge. Volatility in both the petroleum and agricultural commodity markets partially helps to explain why the corn ethanol industry is hesitant to expand capacity in the absence of more-substantial government economic incentives and price-control policies. For biodiesel from soybeans at a price of $\$ 235$ per ton ( $\$ 7.05$ per bushel) and with a yield of roughly 52 gallons per ton, feedstock adds a cost of $\$ 4.52$ per gallon to the fuel production cost before coproduct and federal tax credits.

For advanced biofuel production, most cellulosic biomass conversion processes should operate at efficiencies approaching $50 \%$, implying that a $\$ 10$ per ton increment in feedstock cost will add $\$ 0.15$ per gge, or for ethanol roughly $\$ 0.10$ per gallon. Total near-term production costs, assuming enzymatic conversion technology can be sufficiently commercialized, have been estimated at $\$ 2.46$ per gallon ( $\$ 3.83$ per gge) after taxes for a California facility that produces 70 million gallons per year of cellulosic ethanol with feedstock at $\$ 45$ per ton (Williams 2007). Operating expenses 
other than feedstock are $\$ 0.57$ per gallon or $23 \%$ of total cost (partially offset by net electricity exports worth $\$ 0.09$ per gallon) and capital recovery is $\$ 1.02$ per gallon or more than $40 \%$ of cost.

Feedstock amounts to more than a third of production costs. Improvements in ethanol yield from 70 to 100 gallons per ton of feedstock and decreased enzyme costs from $\$ 0.35$ to $\$ 0.10$ per gallon would reduce production costs to around $\$ 1.85$ per gallon (\$2.16 per gge), closer to the federal target for 2012 of $\$ 1.33$ per gallon of ethanol. Improvement in cellulosic conversion technologies must proceed rapidly if biofuel mandates

\section{References}

[CARB] California Air Resources Board. 2009. Low Carbon Fuel Standard Program. Sacramento, CA. www.arb.ca.gov/fuels/lcfs/lcfs.htm.

[CDFFP] California Department of Forestry and Fire Protection. 2005. Biomass Potentials from California Forest and Shrublands Including Fuel Reduction Potentials to Lessen Wildfire Threat. PIER Consultant Report, Contract 500-04-004.

[EIA] Energy Information Administration. 2009. International Energy Outlook. www.eia.doe.gov/oiaf/ieo/ index.html.

Gildart MC, Williams RB, Yan L, et al. 2006. An assessment of biomass resources in California. California Biomass Collaborative/California Energy Commission/Contract 500-01-016. Sacramento, CA.

Jenkins BM. 2005. Biomass in California: Challenges, opportunities and potentials for sustainable management and development. California Biomass Collaborative/California Energy Commission/CEC500-2005-160. Sacramento, CA

Jenkins BM (ed.). 2006. A roadmap for the development of biomass in California. California Biomass Collaborative/California Energy Commission/CEC 500-2006-095-D. Sacramento, CA

Jenkins BM, Baxter LL, Miles Jr TR, Miles TR. 1998. Combustion properties of biomass. Fuel Process Technol 54:17-46

Parikka M. 2004. Global biomass fuel resources. Biomass Bioenergy 27:613-20.

Parker N, Tittmann P, Hart Q, et al. 2008. Strategic assessment of bioenergy development in the west: Spatial analysis and supply curve development. Western Governors' Association, Denver, CO. www.westgov.org/wga/initiatives/transfuels/index.html.

Perlack RD, Wright LL, Turhollow AF, et al. 2005 Biomass as Feedstock for a Bioenergy and Bioproducts Industry: The Technical Feasibility of a Billion-Ton Annual Supply. Oak Ridge National Laboratory/TM2005/66. Oak Ridge, TN.

Rogner HH. 1997. An assessment of world hydrocarbon resources. Annu Rev Energy Environ 22:217-62. under the new federal energy legislation are to be met on schedule.

\section{Biomass challenges for California}

A wide variety of conversion technologies are currently under development, but large-scale demonstrations of biorefineries producing biofuels from lignocellulosic feedstocks and advanced power-generation options must be completed before commercially successful approaches can be identified and full technical, cost and environmental performance are known. Air emissions will be a dominant concern for new facilities in most regions, especially for power generation, but water supplies, water

Searchinger T, Heimlich R, Houghton RA, et al. 2008. Use of U.S. croplands for biofuels increases greenhouse gases through emissions from land-use change. Science 319:1238-40.

Shaffer S, Paredes L, Summers M, et al. 2009. Feasibility of biomass energy production to support local water self-sufficiency, Western Governors' Association, Denver, CO. January.

Shapouri H, Salassi M. 2006. The economic feasibility of ethanol production from sugar in the United States. US Department of Agriculture, Washington, DC. www.usda.gov/oce/EthanolSugarFeasibilityReport3.pdf.

Sheehan J, Dunahay T, Bennemann J, Roessler P. 1998. A look back at the U.S. Department of Energy's aquatic species program - biodiesel from algae. NREL/TP-580-24190. National Renewable Energy Laboratory, Golden, CO.

Stapleton JJ, Banuelos GS. 2009. Biomass crops can be used for biological disinfestation and remediation of soils and water. Cal Ag 63(1):41-6.

Strittholt JR, Tutak J. 2009. Assessing the impact of ecological and administrative considerations on forest and shrubland biomass projections for California. Conservation Biology Institute, Corvallis, OR. April.

Tittmann P, Parker N, Hart Q, et al. 2008. Economic potential of California biomass resources for energy and biofuel. California Energy Commission/Contract 500-01-016. Sacramento, CA.

[US EPA] US Environmental Protection Agency. 2009 EPA Lifecycle Analysis of Greenhouse Gas Emissions from Renewable Fuels. EPA-420-F-09-024. May. www.epa.gov/otaq/renewablefuels/420f09024.htm (accessed Aug. 22, 2009).

Williams RB. 2007. California biomass and biofuels production potential. Final report, TIAX LLC Research Agreement 07-003016. UC Davis.

Wright LL, Walsh M, Downing M, et al. 2000 Biomass feedstock research and development for multiple products in the United States. First World Conference and Exhibition on Biomass for Energy and Industry. Sevilla, Spain. quality and waste disposal will also be critical determinants in siting and financing. Performance-based sustainability metrics and standards or other instruments providing clear industry guidance will be important over the near term if financing and commercial development are to occur on the scale needed to meet existing state bioenergy targets. Permitting complexity and cost are frequently cited as substantial hurdles, but regulatory processes will increasingly need to address global, state and regional impacts and cross-media effects in addition to local impacts.

Increasing feedstock costs and declining ethanol market prices have resulted in the recent loss of in-state corn biorefining capacity. The longer-term economic prospects for biofuel production are more favorable, however, as long as cellulosic feedstock costs, which are projected to constitute about a third of total production costs, remain less volatile compared with grain and sugar prices. If transportation-fuel costs continue to rise without a concurrent expansion in electric-vehicle capacity in the state or escalation in renewable electricity prices, increasing competition for biofuel feedstocks will occur at the expense of electricity generation. The implications for overall efficiency, greenhouse-gas emissions, and local pollutant emissions and exposures must be considered at the systems level in order to apply incentives to meet existing policy targets and design new policies to encourage development.

B.M. Jenkins is Professor, Department of Biologi$\mathrm{cal}$ and Agricultural Engineering, and Director, UC Davis Energy Institute; R.B. Williams is Development Engineer, Department of Biological and Agricultural Engineering; N. Parker is Graduate Student Researcher, Transportation Technology and Policy Graduate Group; P. Tittmann is Graduate Student Researcher, Geography; Q. Hart is Programmer, Department of Land, Air, and Water Resources; M.C. Gildart is Staff Analyst, California Biomass Collaborative; S. Kaffka is Extension Specialist, Department of Plant Sciences, and Executive Director, California Biomass Collaborative; and B.R. Hartsough is Professor, and P. Dempster is Graduate Student Researcher, Department of Biological and Agricultural Engineering; all are with UC Davis. 